\title{
Historical gender change in West Frisian
}

\author{
Willem Visser
}

Received: 18 March 2009/Accepted: 19 April 2010/Published online: 9 June 2010

(C) The Author(s) 2010. This article is published with open access at Springerlink.com

\begin{abstract}
In Frisian, grammatical gender is an abstract lexical property, which is not spelled out on the noun. It manifests itself in an indirect way, through the agreement relations the noun enters into. It is, thus, understandable that phonological regularities and residual (abstract) case marking in a prepositional context can be crucial for two instances of historical gender change in Frisian. In the DutchFrisian language contact situation, however, factors which are strictly speaking non-linguistic in nature play a role as well. These are, first, the low degree of standardisation of Frisian at the time the gender change set in and, secondly, distancing from Dutch at the time when Frisian developed its own standard vis-à-vis Dutch, which implies the propagation of the gender which diverges from the Dutch one. It is the interplay between these factors which lends the case of gender change in Frisian an inherent linguistic significance. Not every Frisian de-word could become an it-word and vice versa, since the language system puts its limits here. For instance, all nouns ending in schwa are de-words, a formal regularity which prevented them from switching to it-words. Neither are there only regular patterns of gender change in Frisian. The general tendencies are clear, but as far as individual words are concerned, there is much which must be left unexplained.
\end{abstract}

Keywords Gender · Gender assignment · Gender change $\cdot$ Minority language

\footnotetext{
W. Visser $(\bowtie)$

Fryske Akademy, Linguistics Department, P.O. Box 54, 8900 AB Ljouwert/Leeuwarden, The Netherlands

e-mail: wvisser@fryske-akademy.nl; w.visser@rug.nl

W. Visser

University of Groningen, Centre for Language and Cognition Groningen, P.O. Box 716, 9700 AS Groningen, The Netherlands
} 
Wy spreeken veele met het, die andere met de zeggen: met de, die andere met het. ${ }^{1}$

Johannes Hilarides (1705:23)

\section{Introduction}

One of the structural resemblances between Modern West Frisian (henceforth: Frisian) and Dutch is that both languages have a comparable gender system, as illustrated by the use of the definite article. See the examples in (1):

(1) Dutch Frisian gloss

Non-neuter nouns

$\begin{array}{lll}\boldsymbol{d} \boldsymbol{e} \text { tijd } & \boldsymbol{d} \boldsymbol{e} \text { tiid } & \text { the time } \\ \boldsymbol{d} \boldsymbol{e} \text { dag } & \boldsymbol{d} \boldsymbol{e} \text { dei } & \text { the day } \\ \boldsymbol{d} \boldsymbol{e} \text { huur } & \boldsymbol{d} \boldsymbol{e} \text { hier } & \text { the hire, the rent }\end{array}$

Neuter nouns

$\begin{array}{lll}\text { het haar } & \text { it hier } & \text { the hair } \\ \text { het } \text { ruim } & \text { it } \text { rom } & \text { the hold (of a ship) } \\ \text { het } \text { beest } & \text { it } \text { bist } & \text { the beast; the animal }\end{array}$

The articles have the same pronunciation in both languages. This not only holds for Frisian and Dutch de, which are homographs, but also for the neuter article. Although the latter is written as $<$ het $>$ in Dutch and as $<$ it $>$ in Frisian, both have the pronunciation [ət].

In spite of this, there are a good many Frisian nouns whose gender differs from that of their Dutch cognates. For instance, whereas Dutch has de plek 'the spot' and de schaduw 'the shade, the shadow', Frisian has it plak and it skaad (see (4), (11), and (14) below for full lists). These differences are noted in every school grammar of Frisian, most of which of necessity pay quite some attention to a contrastive analysis between Frisian and Dutch. ${ }^{2}$ Generally speaking, Dutch has stuck to the old gender here, while Frisian has undergone an innovation.

In Frisian, the grammatical gender of simplex nouns is a lexical property of these nouns. It is, however, an abstract property, which is not 'spelled out' on the nouns or, put differently, which does not have a direct morphological expression. It only manifests itself indirectly, by means of the agreement relations the nouns enter into.

An obvious source of gender change, therefore, is the reinterpretation of surface forms. As to Frisian, the two most powerful diachronic mechanisms in this respect are the reinterpretation of the common article $d e$ as the neuter article it in a context

\footnotetext{
1 Translation: we [the Frisians] say many [nouns] with het, which others [the Dutch] say with de; with de, which others [say] with het.

2 Nowadays, under the influence of Dutch, such nouns are often used with the article which is homophonic with the Dutch one, as in de kin 'the chin' (instead of it kin; cf. Dutch de kin), de sop 'the soup' (instead of it sop; cf. Dutch de soep), de skouder 'the shoulder' (instead of it skouder; cf. Dutch de schouder), see for instance De Haan (1997). This, however, is strongly rejected in Standard Frisian.
} 
where the former had become indistinguishable from the latter as a result of phonological adaptation, and the reinterpretation of neuter it as common de in a prepositional context—synchronically speaking, mostly in frozen expressions-in which case-marked it had the same form as de.

The specific Frisian-Dutch language contact situation contributed to the persistence of the gender change. In Standard Frisian, in order to maximise the linguistic distance between the two languages, those Frisian articles were, and are, favoured which are the opposite of the Dutch ones.

So, next to the linguistic factors inducing the change, sociological factors made for its persistence. It is the interplay between these factors which lends the case of gender change in Frisian an inherent significance.

\section{Gender and gender assignment in Frisian}

As exemplified in (1) above, Frisian has two grammatical genders, viz. neuter and non-neuter (also called common gender). Instead of using these terms, it has become customary in Frisian linguistics to divide the nouns in accordance with their definite article. Hence, there are $d e$-words (non-neuter) and $i t$-words (neuter), see Tiersma (1985, 47-49), Hoekstra and Visser (1996), Hoekstra (2001, 89).

For simplex nouns there is not a clear-cut semantic or formal relationship between the noun and its article. This means that the definite article a noun is associated with is one of its lexical properties. ${ }^{3}$ There is, for instance, no inevitable relation between $k o$ 'cow' and the article de, as little as between skiep 'sheep' and the article it. A child acquiring Frisian simply has to learn the right article on a word-by-word-basis. ${ }^{4}$

There are, however, certain tendencies and subregularities as to gender assignment in Frisian. As regards semantic relationships, the animacy hierarchy plays a role, as it does in many languages (see Croft 2003, 166-175, 178-182). For Frisian, the overall effect of this hierarchy on gender assignment is that nouns denoting living creatures, which occupy high ranks in the hierarchy, have a preference for $d e$. The class of animates, in turn, shows a further partitioning in nouns which denote human beings and those denoting animals; the former more strongly prefer de than do the latter, as is also observed for Dutch by Booij $(2002,37){ }^{5}$ Not only can nouns

\footnotetext{
3 In the (Frisian) dialect of the island of Schiermonnikoog-which still distinguishes three genders-feminine gender is assigned to nouns with a concrete reference only, like daar 'door', tjark 'church', deeuw 'pigeon', and haun 'hand', whereas masculine and neuter nouns can refer to both concrete and abstract nouns. Besides, with a few exceptions, feminine nouns are monosyllabic, while masculine and neuter nouns can comprise more than one syllable. In Schiermonnikoogs, then, there seems to be a semantic and a formal relationship between a noun and feminine gender. See Spenter (1971) for more on this.

4 This also holds for Dutch, see Booij (2002, 36-39), who asserts: "Even if the linguist is able to find certain subregularities or tendencies in gender assignment based on semantic or phonological properties, the question remains if native speakers really grasp these generalizations. (...) It is clear then that gender is a burden for the lexical memory of the speaker of Dutch because it has to be memorized for many nouns, and certainly for most simplex nouns".

5 The it-words bern 'child', minske 'soul, woman', and wiif 'wife; bitch' are well-known for not being in keeping with this tendency. The fact that they refer to children and, in an affective/pejorative sense, to women might be of relevance.
} 
denoting animals have it, cf. it skiep above, some have it alongside de, e.g. de/it knyn 'the rabbit', de/it ei 'the ewe', de/it ezel 'the donkey', de/it kamiel 'the camel', and de/it inter 'the yearling'.

Nouns which denote inanimates, on the other hand, are more likely to have it than those which denote living creatures, let alone human beings. Names for metals, languages, and the directions of the wind, for instance, all have it, as the following examples make clear: it stiel 'the steel', it Dútsk 'German, the German language', and it noarden 'the North'.

Next to semantically motivated patterns of gender assignment, there are also instances of formal relationships between nouns and their article. With a few exceptions, nouns ending in $<\mathrm{e}>(/ \mathrm{\partial} /),<\mathrm{el}>(/ \mathrm{\partial l} /)$, and $<\mathrm{em}>(/ \mathrm{\partial m} /)$ have the article de, e.g. de bile 'the axe', de sichte 'the sickle, the reaping hook, ${ }^{6} \boldsymbol{d e}$ apel 'the apple', de woartel 'the root; the carrot', de biezem 'the broom', and de wazem 'the steam, the vapour'. Here, then, there is a relation between the phonological shape of the noun - typically pertaining to the right-hand part of it — and the gender it is allotted to.

Complex nouns yield a markedly different picture. Due to right-headedness, the choice of article is determined by the right-hand morphological part of the word, i.e., the right hand member (in case of a compound), the suffix (in case of suffixation), or the stem (in case of prefixation). ${ }^{7}$ See the examples in (2):

(2) Choice of article in complex nouns

a. Compounds

$\begin{array}{ll}\text { it fjild 'field, grounds' } & \rightarrow \text { de fjildsport 'the outdoor sports' } \\ + \text { de sport 'sports' } & \\ d e \text { sport }+ \text { it fjild } & \rightarrow \text { it } \text { sportfjild 'the sports field' }\end{array}$

b. Diminutives 8

de peal 'post, pole' _ $\quad$ it pealtsje (peal+tsje) 'small post, pole'

de baarch 'pig'

de doar 'door'

it barchje (baarch+je) 'piglet'

it doarke (doar+ke) 'small door'

c. Prefixed words

it lân 'land'

- $\quad$ it ûnlân (ûn+lân) 'the marshland'

it dak 'roof'

it oerdak (oer+dak) 'the lean-to'

\footnotetext{
${ }^{6}$ See Visser (1997, 237-240) on nouns ending in $<\mathrm{e}>(/ \mathrm{\partial} /)$; see also the end of $\S 5.1$ below, especially the examples of schwa-final $d e$-words in (10).

7 According to Booij $(2002,37)$, the same goes for Dutch.

8 This also holds for those nouns which are only diminutives in a formal, but not in a semantic sense, like it ingeltsje (ingel+tsje) 'the ladybird, the lady beetle' (literally: little angel; from: $\boldsymbol{d e}$ ingel) and it karke (kar+ke) 'the invalid chair, the wheelchair' (literally: small cart; from: de karre).
} 


\section{Frisian in relation to Dutch}

Because this will play a role in my analysis, let me make some general remarks on Frisian, especially on its relationship to Dutch.

Frisian is a minority language, spoken by about 450,000 of the 600,000 inhabitants of Friesland, a province in the northwest of the Netherlands. The national language of the Netherlands is (Standard) Dutch, which is therefore the dominant language in the public domain (politics, culture, education, economics). This means that all speakers of Frisian are at least bilingual, i.e., they are fluent in both Frisian and Dutch.

From the nineteenth century onwards the Frisian language movement has made constant efforts to further the use of Frisian in the public domain, notably politics, education, church, the media, cultural life (literature and music), and science (Frisian linguistics and (local) history), in order to reply to the increasing dominance of Dutch. These efforts have certainly not been without result. Frisian has been acknowledged as the second official language of the Netherlands, as a result of which it has acquired certain rights in government at the provincial and municipal level. In education, too, it now has certain rights at both the level of primary and secondary education and the university level (one can graduate in Frisian linguistics and literature). The bible has been translated twice (in 1943 and 1978) and the use of Frisian in religious services is no longer uncommon. Radio and televison programmes in Frisian are broadcast every day. There are quite a few Frisian periodicals and journals, whereas there is a lively literary climate and a steady literary production. There are also a lot of Frisian (folk) rock groups which use Frisian in whole or in part. Nevertheless, the supremacy of Dutch is counterbalanced to no more than a small extent.

Frisian is a West Germanic, to be precise, a North Sea Germanic language. Of the continental Old Germanic dialects, it is Old Frisian that is most closely related to Old English (see Nielsen 1981). There are still remnants of this close historical affinity, which manifest themselves mainly in the lexicon and in the lexical phonology-for example, the Frisian cognates of key, church, and to bleed are kaai, tsjerke, and bliede, respectively. Dutch, however, has exerted a profound influence on Frisian for some centuries, so Frisian bears a much greater resemblance to Dutch than it does to English, both lexically and structurally.

\section{Gender change in Frisian}

As noted in the introduction, the grammatical gender of a Frisian simplex noun is a lexical property of this noun. It is, however, an abstract property, which does not have a direct morphological expression. It only manifests itself indirectly, by means of the agreement relations the noun enters into. There is agreement between the noun and its accompanying definite article, other determiners, and relative pronouns and between the noun, the indefinite article, and a prenominal adjective, as illustrated in (3): 
(3) Gender agreement relations

a. Between the noun and the definite article, other determiners and the relative pronoun

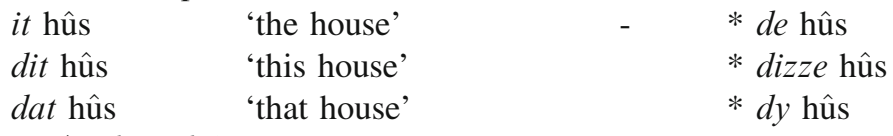

it hûs $d a t{ }^{*} d y$ 't ik kocht haw

the house which I bought have

'the house which I have bought'

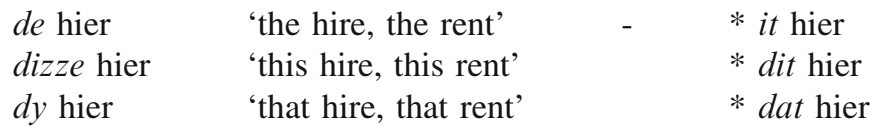

de hier $d y^{\prime} t{ }^{*}$ dat ik betelje moat

the rent which I pay must

'the rent which I have to pay'

b. Between the noun, the indefinite article, and the prenominal adjective it/dit/dat lege/*leech hûs in leech/*lege hûs 'the/this/that empty house' 'an empty house'

de/dizze/dy lege/*leech hier in lege/*leech hier

'the/this/that low rent'

'a low rent'

The gender of a noun, thus, is only detectable from the context in which the noun shows up. This means that the reinterpretation of surface forms is an important source of gender change.

There are two kinds of such 'surface-oriented' gender change, the reinterpretation of the common article $d e$ as the neuter article it in a specific phonological context and the reinterpretation of neuter it as common $d e$ in a prepositional context. These will be treated below, in $\S \S 5$ and 6, respectively.

\section{From de-word to it-word}

This section consists of four subsections, the first three of which are devoted to different, though comparable, classes of Frisian it-words with Standard Dutch $d e$-word counterparts. These are nouns with an initial voiceless obstruent $(§ 5.1)$, nouns denoting outer body parts $(\S 5.2)$, and residual cases $(\S 5.3)$. The final subsection $(\S 5.4)$ reflects on the differences between Dutch and Frisian as to gender change and the specific role played by the Frisian-Dutch language contact situation in this respect.

\subsection{Nouns with an initial voiceless obstruent}

This subsection deals with Frisian it-words with an initial voiceless obstruent which have cognate Dutch $d e$-word as counterpart. In (4) I list the cases I have been able to find: 
(4) Nouns with an initial voiceless obstruent

\begin{tabular}{|c|c|c|}
\hline Frisian & Dutch & gloss \\
\hline it fabryk & $d e$ fabriek & the factory \\
\hline it kajút & de kajuit & the saloon (of a ship) \\
\hline it kâlt & de kout & the confabulation \\
\hline it $\mathrm{ke}(\mathrm{a}) \mathrm{tting}$ & de ketting & the chain \\
\hline it plak & de plek & the spot \\
\hline it $\sin$ & de $\operatorname{zin}$ & the mind, the liking \\
\hline it skaad $^{9}$ & de schaduw & the shade, the shadow \\
\hline it slaad & de sla & the lettuce \\
\hline it sop & de soep & the soup \\
\hline it stee(d) & de stee & the spot \\
\hline it string & de streng & the twist, the twine \\
\hline it tiksel & de dissel & the pole, the shaft, the thill \\
\hline
\end{tabular}

As they refer to all kinds of entities, the nouns in (4) do not form a semantic class. This means that the change of gender here cannot be attributed to a new semantic gender assignment rule of Frisian.

The impetus for the change, therefore, must not be sought in semantics, but elsewhere. What I would like to propose, following an approach put forward by Pauwels (1931), is that it be sought in phonology, to be more precise, in cliticisation and the phonological effects ensuing from it. ${ }^{10}$

The articles de and it have schwa as their only vowel. Schwa is too weak a vowel to license a phonological word, so the article cannot stand on its own and has to lean, as it were, against a host word for phonological support.

When acting as proclitics, the articles de and it are adjoined to the following phonological word. ${ }^{11}$ With nominal phrases, like de sin 'the mind, the liking' and de skaad 'the shade, the shadow', this proceeds as in (5):

\footnotetext{
9 The following quote from early Modern Frisian shows that skaad was originally a de-word:

Hir ijn de schoad [skaad] vin 't beammig woad

here in the shade of the treey wood

'here in the shade of the treey woods'
}

(Brouwer (ed.) 1959, 50, line 25)

${ }^{10}$ In many languages, the phonological shape of nouns plays a role in gender assignment regularities. These, as a rule, pertain to coda rather than onset segments (see for example Thornton 2009). In the case at hand, however, it is the onset of the noun that is crucial. It should be borne in mind, however, that this article deals with gender change, which is related to, but not the same as, gender assignment.

11 See Visser (1988a) for cliticisation in Frisian in general. Arguments why proclitics and prefixes are integrated into prosodic structure by means of adjunction to the (following) phonological word are provided by Booij (1995, chapter 8, 1996) for Dutch and by Visser (1997, 292-296) for Frisian. Visser (1990) is devoted to (en)cliticisation of the definite article in Frisian in a historical perspective. 
(5) Adjunction of the article de to the following phonological word
$(\mathrm{d} ə)_{\sigma}\left((\sin )_{\sigma}\right)_{\omega}$
$\rightarrow$
$\left((\mathrm{d} ə)_{\sigma}\left((\sin )_{\sigma}\right)_{\omega}\right)_{\omega}$
$(\mathrm{də})_{\sigma}\left((\mathrm{ska}: \mathrm{t})_{\sigma}\right)_{\omega}$
$\left((\mathrm{də})_{\sigma}\left((\text { ska:t })_{\sigma}\right)_{\omega}\right)_{\omega}$

Preferably, the first syllable of a phonological word in Frisian has a full vowel, the unmarked foot type being the trochee (see Visser 1997, 269-270). The outcome of cliticisation in (5) is at odds with this preference. This means that phonological pressure will be exerted on this kind of structure to the effect that it be brought in line with the unmarked trochaic pattern. Schwa is the minimal vowel of Frisian, consisting of no more than a vocalic root node (see Visser 1997, 34-38)). It is, therefore, prone to insertion and deletion, both of which are minimal steps. If schwa deletes, it results in the collapse of the syllable it is the head of, in accordance with the principle of 'parasitic delinking', which states that "[s]yllable structure is deleted when the syllable contains no overt nuclear segment" (Hayes 1989, 268). What is left of the article de after schwa deletion, then, is no more than a bare, floating $d$. The incorporation of this $d$ into the prosodic word associated with the noun is the only way to save it from deletion. All this is depicted in (6):

(6) Schwa-deletion and restructuring of prosodic structure

$$
\begin{aligned}
& \left((\mathrm{d} \vartheta)_{\sigma}\left((\mathrm{sin})_{\sigma}\right)_{\omega}\right)_{\omega} \quad \rightarrow \quad\left(\mathrm{d}(\mathrm{sin})_{\sigma}\right)_{\omega} \quad \rightarrow \quad\left((\mathrm{dsin})_{\sigma}\right)_{\omega} \\
& \left((\mathrm{d} \vartheta)_{\sigma}\left((\mathrm{ska}: \mathrm{t})_{\sigma}\right)_{\omega}\right)_{\omega} \quad \rightarrow \quad\left(\mathrm{d}(\mathrm{ska}: \mathrm{t})_{\sigma}\right)_{\omega} \quad \rightarrow \quad\left((\mathrm{dska}: \mathrm{t})_{\sigma}\right)_{\omega}
\end{aligned}
$$

If the noun begins with an obstruent, schwa deletion results in an obstruent cluster. A property of such clusters is that its members must share their voice specification, hence the entire cluster must end up as either voiced or voiceless. ${ }^{12}$ What is left of the article de, i.e. voiced $d$, remains voiced before a noun with an initial vowel or voiced consonant; however, $d$ devoices when the following noun begins with a voiceless obstruent. The article it meets with the same fate (but see below). What is left of it after schwa deletion, voiceless $t$, remains voiceless before a noun with a (voiced) initial sonorant segment and a voiceless obstruent, but $t$ is voiced before a following noun beginning with a voiced obstruent. The latter can only be a plosive, since word-initial voiced fricatives are prohibited in Frisian (see also below). The voicing possibilities for $d(d e)$ and $t$ (it) are shown in (7):

$$
\begin{aligned}
& \text { a. Voicing possibilities of } d(d e) \\
& \mathrm{d} \rightarrow \mathrm{d} / \_ \text {word with an initial vowel } \\
& \text { word with a voiced initial consonant }
\end{aligned}
$$

\footnotetext{
12 To this effect, Lombardi $(1999,272)$ formulates the constraint AGREE, reading "Obstruent clusters should agree in voicing".
} 
Examples of devoicing with the words de sin 'the mind, the liking' and de skaad 'the shade, the shadow':

$$
\begin{array}{lll}
\left((\mathrm{dsin})_{\sigma}\right)_{\omega} & \rightarrow & \left((\mathrm{tsin})_{\sigma}\right)_{\omega} \\
\left((\mathrm{dska}: \mathrm{t})_{\sigma}\right)_{\omega} & \rightarrow & \left((\mathrm{tska}: \mathrm{t})_{\sigma}\right)_{\omega}
\end{array}
$$

b. Voicing possibilities of $t$ (it)

$\mathrm{t} \rightarrow \mathrm{t} / \ldots$ word with an initial sonorant segment

_ word with a voiceless initial obstruent

$\mathrm{d} / \ldots$ word with a voiced initial plosive

Examples of voicing with the words it bier 'the beer, the ale' and it gea 'the region, the area':

$$
\begin{aligned}
& \left((\text { tbi.ər })_{\sigma}\right)_{\omega} \rightarrow\left((\text { dbi.ər })_{\sigma}\right)_{\omega} \\
& \left((\operatorname{tgl} . ə)_{\sigma}\right)_{\omega} \rightarrow\left((\operatorname{dgl} . ə)_{\sigma}\right)_{\omega}
\end{aligned}
$$

When the article de frequently shows up as $t$ before a voiceless obstruent, this $t$ can become equated with the reduced variant of the article $i t$. In the end, this may lead to the reanalysis of $t$ as $i$, hence to a change of gender, as illustrated in (8):

(8) Reinterpretation and reanalysis of the reduced and devoiced article de as the article $i t$

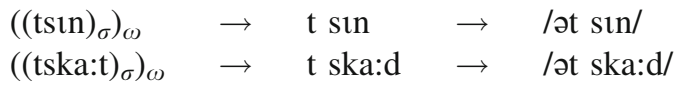

Some remarks are in order here. In the first place, (4) only lists instances of the change from de to it. This is more likely than the opposite change, viz. from it to de. First of all, there is the distributional fact that both voiced and voiceless plosives can occur word-initially in Frisian, whereas of the fricatives only the voiceless series is allowed in that position (Tiersma 1985, 24-26); this increases the overall number of words beginning with a voiceless obstruent. Secondly, the voiceless fricative $s$ is by far the most frequent word-initial consonant in Frisian. ${ }^{13}$ Because of the unequal distribution of voiced and voiceless obstruents in word-initial position and the high frequency of $s$ in that position, the article de simply has a greater chance to meet a devoicing factor than it has to meet a voicing one. Therefore, the chance of the article de showing up as voiceless $t$ is much greater than the chance of the article it showing up as voiced $d$, implying, in turn, that the change from de to it is more likely than the opposite one. This shows the influence phonology may have on gender change. In this respect, it should be noted that the great majority of the words in (4) are monosyllabic, non-derived words, which means that gender change is not counterbalanced by the influence suffixes or word endings may have on gender assignment.

\footnotetext{
13 The Frysk Wurdboek (1984) has 1192 pages, 183 of which are devoted to words with initial $s$. This is about $15 \%$ of the total number. If the letters of the alphabet were equally distributed, each one of them were to occupy about $4 \%$ of this number.
} 
The noun sticks to its underlying form here, whereas the article undergoes phonological adaptation, viz. regressive devoicing. This is in agreement with a general difference between phonological conditions on the shape of major class words (content words) and minor class words (function words), all of which testify to the fact that the former class is more prominent and 'stronger' than the latter (see Dresher and Van der Hulst 1998, 336-337).

But this doesn't alter the fact that progressive voicing in [dsin] and [dska:t] could hypothetically yield an outcome, viz. [dzin] and [dzga:t], which is consistent with the general requirement that obstruent clusters agree in voicing (see footnote 12). Regressive voicing, however, links up with the fact that regressive assimilation is the unmarked instance of assimilation in Frisian, see Tiersma (1985, 26-28), Visser (1988b), Hoekstra $(2001,86) .{ }^{14}$ There is a universal preference for onset segments to stick to their (underlying) voicing value, which is often at the expense of the voicing value of a preceding coda consonant or, put differently, which induces regressive voicing assimilation in case of a voicing conflict. Moreover, the change from [dsin] and [dska:t] into [dzın] and [dzga:t] cannot be followed by the reinterpretation of the parts -[zin] and -[zga:t] as the new underlying forms /zin/ and /zga:d/. As noted above, voiceless fricatives are not allowed in word-initial position. The reinterpretation of -[zga:t] as /zga:d/ is all the more impossible, because in Frisian the voiced velar plosive /g/ is only allowed in word-initial position or at the beginning of a stressed word-internal syllable (Tiersma 1985, 25; Hoekstra 2001, 86), so it cannot be the final segment of a word-initial cluster. All in all, the change from it to $d e$ is highly unlikely to take place according to the above scenario.

All this, however, leaves unexplained why the phonologically induced change from de to it is not parallelled at all by the opposite but comparable change from it to $d e$, no matter how less likely the latter may be. Put differently, why is it that there are no instances of the reanalysis of, for example, dbier and dgea-see (7b) above-as de bier and de gea? This is all the more puzzling, since the change from $i t$ to $d e$ would have been in keeping with the ratio between $d e$-and $i t$-words in the lexicon of Frisian, where, due to the common historical coalescence of the masculine and feminine gender, $d e$-words are in the majority. I have no clear and unequivocal answer to offer.

When the change from it to de does occur, it takes a non-phonological route, which I will deal with in Sect. 6 below.

The change from de to it must have set out as an alternation between the full form of the article, $d e$, and its reduced and phonologically adapted variant, $t$. Some lexicalised collocational prepositional phrases still show the traces of this alternation, witness the following three cases: ${ }^{15}$

\footnotetext{
14 I deliberately talk of progressive 'voicing' or 'adaptation' here, since in Frisian regular (regressive) assimilation only takes place between phonological words, whereas the phonological word itself is the domain of phonological adaptive processes, among which also progressive ones.

15 See (17) below for nouns displaying the same kind of alternation, viz. between the article it in free use and $d e(' e)$ when being part of a collocational prepositional phrase.
} 
(9) Alternation between de and $t$ in lexicalised collocational prepositional phrases

a. With the preposition by 'by', in collocations denoting a huge amount

\begin{tabular}{|c|c|c|}
\hline de soad & - $\quad$ by 't $t$ soad & $\begin{array}{l}\text { 'the amount to be cooked - } \\
\text { in abundance, in plenty, galore' }\end{array}$ \\
\hline de seksje & - by't seksje & 'section - in abundance' \\
\hline de poarsje & - by ${ }^{\prime} t$ poarsje & 'portion - in abundance' \\
\hline de oper & by 't $t$ oper & 'hay cock - in abundance' \\
\hline
\end{tabular}

b. With the prepositions fan 'of' and by 'during', with nouns denoting time spans, notably the seasons

$\begin{array}{llll}\boldsymbol{d} \boldsymbol{e} \text { simmer } & - & \text { fan/by' } \boldsymbol{t} \text { simmer } & \text { 'summer - in (the) summer' } \\ \boldsymbol{d} \boldsymbol{e} \text { hjerst } & - & \text { fan/by' } \boldsymbol{t} \text { hjerst } & \text { 'autumn - in (the) autumn' } \\ \boldsymbol{d} \boldsymbol{e} \text { winter } & - & \text { fan/by' } \boldsymbol{t} \text { winter } & \text { 'winter - in (the) winter' } \\ \boldsymbol{d} \boldsymbol{e} \text { maitiid } & - & \text { fan/by' } \boldsymbol{t} \text { maaityd } & \text { 'spring - in (the) springtime' } \\ \boldsymbol{d} \boldsymbol{e} \text { wike } & - & \text { fan' } \boldsymbol{t} \text { wike } & \text { 'week - this week' }\end{array}$

c. Residual cases

$\begin{array}{llll}\boldsymbol{d} e \text { spier } & - & \text { yn' } t \text { spier (wêze) } & \text { 'muscle - to be up and at it' } \\ d e \text { set } & - & \text { fan't } t \text { set (wêze) } & \text { 'move - to be out of sorts, in a tizzy' }\end{array}$

For this phonological approach to work, all nouns in question must begin with a voiceless obstruent (see (7a) above). This is confirmed by (9a), although the fourth case, the vowel-initial noun oper, does not fit in with the pattern. The approach is also confirmed by (9c), and especially by (9b), where ' $t$ is fixed in fan/by' $t$ simmer only, while the other nouns, alongside fan 't -fan 't hjerst, fan 't winter, fan 't maaityd, fan't wike - also have the variant fan' $\boldsymbol{e}$, in which the article de, following the monosyllabic preposition fan, has the regular reduced variant' $\boldsymbol{e}$ : fan' $\boldsymbol{e}$ hjerst, fan ' $\boldsymbol{e}$ winter, fan' $\boldsymbol{e}$ maaityd, fan' $\boldsymbol{e}$ wike. ${ }^{16} \mathrm{Here}$, then, we find a clear difference between the noun with the voiceless initial obstruent /s/ and the ones with a voiced initial segment_/v/ (wike, winter), /m/ (maaityd), / j/ (hjerst)—, suggesting that the alternation between $d e$ and $t$ is most prominent with simmer, the noun with which it is likely to have set out. ${ }^{17}$

\footnotetext{
16 These are cases of encliticisation of the article ' $e$ (de) onto the (preceding) preposition, yielding an optimal prosodic structure, i.e., a trochee. The article de is prone to both encliticisation and procliticisation, irrespective so it seems of the prosodic outcome.

17 Standard Dutch has the comparable collocation van 't zomer 'in (the) summer' (cf. de zomer 'the summer'). But - at least according to the most authoritative Dutch desk dictionary, i.e., Van Dales Groot Woordenboek van de Nederlandse Taal - it does not have van't winter 'in (the) winter' (cf. de winter 'the winter') and van't herfst 'in (the) autumn' (cf. de herfst 'the autumn'). This points to a crucial role for nouns with an initial obstruent in the incipience of the alternation at hand.
} 
The occurrence of 't in fan't hjerst, fan't winter, fan't maitiid, and fan't wike is to be explained as an analogical extension of the pattern (construction) fan 't simmer. ${ }^{18}$ An obvious question to ask is how it is to be accounted for that fan 't simmer could act as a 'model' for the other seasons here. An account cannot be based on frequency. In the Frisian Language Databases at the Fryske Akademy in Leeuwarden (http://www.fryske-akademy.nl/tdb), both winter and wike have a higher text frequency than simmer. In $\S 5.2$ below, it is shown that quite a few nouns denoting outer body parts have become it-words, also some non-obstruent-initial nouns, like it wang 'the cheek' and it ankel 'the ankle'. In order to explain these cases, the concepts of semantic analogy or concept association are appealed to, it being the prevailing article in the word field of the outer body parts. The latter, however, does not hold for the word field of the seasons, where there are only de-words (see (9b)). ${ }^{19}$ No doubt, the summertime is experienced as a nice and positive time, with its long days, its summer heat, its summer weather, and the summer holiday. Such extra-linguistic factors, however, are unlikely to make for a real explanation here. So, what really is going on with these nouns is as yet unclear.

Not all nouns beginning with a voiceless obstruent were subject to the gender change of this section. Although many Frisian nouns end in schwa, none of the nouns in (4) do. This is not a coincidence. There is a correlation between noun-final schwa and the article de or, put differently, a schwa-final noun in Frisian cannot be but a $d e$-word. This is nicely illustrated by the fact that for some nouns there is an alternation between a (monosyllabic) it- and a schwa-final de-variant. See the examples in (10)—for the greater part taken from Visser (1997, 237-240)—, all of which begin with a voiceless obstruent:

(10) Monosyllabic it-words next to schwa-final de-words

\begin{tabular}{|c|c|c|}
\hline flym & de flime & 'the lancet' \\
\hline focht & de fochte & 'the liquid; the moisture' \\
\hline koard & de koarde & 'the cord' \\
\hline sou & de souwe & 'the riddle, the sieve' \\
\hline span & de spanne & 'the team (of horses)' \\
\hline spyn & de spine & 'the pantry, the larder' \\
\hline swaard & de swarde & 'the rind' \\
\hline tsjil & de tsjille & 'the wheel' \\
\hline
\end{tabular}

Being schwa-final, the nouns of the right-hand column could not have become $i t$-words, in spite of the support for the neuter gender provided by the it-variants in the left-hand column. Nouns with an initial voiceless obstruent and a final schwa which lack such support, like de file /filə/ 'the file', de seage /sı.ərə/ 'the saw',

\footnotetext{
18 The occurrence of 't in by't oper 'in abundance' in (9a) must be explained along the same lines.

19 The Dutch collocations van't voorjaar 'in (the) springtime' and van't najaar 'in (the) autumn' show the reduced variant ' $t$ of the article het, with which the nouns het voorjaar 'the springtime' (literally: the before-year) and het najaar 'the autumn' (literally: the after-year) are associated. Analogical extension of this pattern did not occur in Standard Dutch; in all likelihood, this has to do with the higher degree of standardisation of Dutch as compared to that of Frisian (see also $\S 5.4$ below).
} 
de tinte /tıntə/ 'the tent', remained de-words as well. So, its phonological shape can prevent a noun from undergoing gender change.

A noun-final schwa, however, did not deprive the article de of the possibility of having the combinatorial variant $t\left\langle^{\prime} t\right\rangle$, as shown by the collocations by't seksje (9a) and fan't wike (9b). There is a sharp distinction between combinatorial variance of the article and (categorical) gender change.

\subsection{Nouns denoting outer body parts}

In (11) below, I list the cases I have been able to find of Frisian it-words denoting outer body parts with a Dutch $d e$-word as counterpart:

(11) Nouns denoting an outer body part (ordered 'top-down')

$\begin{array}{lll}\text { Frisian } & \text { Dutch } & \text { gloss } \\ \text { it } \text { sliep } & \boldsymbol{d} \boldsymbol{e} \text { slaap } & \text { the temple } \\ \text { it } \text { wang } & \boldsymbol{d} \boldsymbol{e} \text { wang } & \text { the cheek } \\ \text { it } \text { kin } & \boldsymbol{d} \boldsymbol{e} \text { kin } & \text { the chin } \\ \text { it } \text { burd } & \boldsymbol{d} \boldsymbol{e} \text { baard } & \text { the beard } \\ \text { it } \text { skouder } & \boldsymbol{d} \boldsymbol{e} \text { schouder } & \text { the shoulder } \\ \text { it } \text { boarst } & \boldsymbol{d} \boldsymbol{e} \text { borst } & \text { the breast } \\ \text { it } \text { spien } & \boldsymbol{d} \boldsymbol{e} \text { speen } & \text { the teat, the nipple } \\ \text { it } \text { bil } & \boldsymbol{d} \boldsymbol{e} \text { bil } & \text { the thigh } \\ \text { it } \text { kût } & \boldsymbol{d} \boldsymbol{e} \text { kuit } & \text { the calf } \\ \text { it } \text { ankel } & \boldsymbol{d} \boldsymbol{e} \text { enkel } & \text { the ankle } \\ \text { it } \text { krop } & \boldsymbol{d} \boldsymbol{e} \text { krop } & \text { the instep (Frisian); the crop, the gizzard, the } \\ & & \text { maw (Frisian and Dutch) }\end{array}$

The pattern in (11) is indicative of the fact that in the course of time Frisian has acquired a semantically motivated gender assignment rule, to the effect that a noun denoting an outer body part became allotted to the it-gender. According to Enger $(2009,1296)$, this rule qualifies as a so-called 'crazy rule', his shorthand for a 'noncore semantic rule'. The initial motivation for this rule is the same as for the gender change of the previous section, i.e., cliticisation of the article de and its

20 The following quotes from early Modern Frisian show that skouder and krop originally were de-words:

Jo ken de tonge oppe [op de] schouder hingje litte

she can the tongue on the shoulder hang let

'she can let her tongue hang on her shoulder' (meaning: she dominates the conversation; she is a scandalmonger, a gossip)

(Van der Kuip 2003, 429, number 602)

Hoe heag iz him de krop

how high is him the crop, gizzard

'how high a crop, gizzard he has' (meaning: how haughty and proud he is)

(Feitsma (ed.) 1956a, 38, number 473a). 
phonological effects. This gave rise to a certain amount of $i t$-words denoting outer body parts, a subpattern which was interpreted semantically and subsequently generalised.

As to the latter, the neuter gender of wang 'cheek', burd 'beard', boarst 'breast', bil 'thigh', and ankel 'ankle' in (11) cannot be explained on phonological grounds, because these nouns do not begin with a voiceless obstruent. For an explanation, one may appeal to the concept of semantic analogy or concept association (Shields 1979, 32-33; Corbett 1991, 75-77). Take the word ankel. Beginning with a vowel, its gender change can by no means be explained on phonological grounds. Besides, since it ends in the sequence -/əl/, one expects it to be a de-word (see $\S 2$ above). Yet, ankel has undergone gender change, for which analogical influence from the whole word field of outer body parts, where it had become the prevalent article, makes a reasonable case. From the knee down to the foot, it now is it kît 'the calf', it ankel 'the ankle', and it krop 'the instep'.

The semantic gender assignment rule at hand, however, is not without exceptions nor has analogy extended its influence to all nouns denoting outer body parts, witness the $d e$-words in (12):

(12) Frisian de-words denoting outer body parts

$\begin{array}{ll}\boldsymbol{d} e \text { noas } & \text { 'the nose' } \\ \boldsymbol{d} \boldsymbol{e} \text { finger } & \text { 'the finger' } \\ \boldsymbol{d} \boldsymbol{e} \text { hân } & \text { 'the hand' } \\ \boldsymbol{d} \boldsymbol{e} \text { earm } & \text { 'the arm' } \\ \boldsymbol{d} \boldsymbol{e} \text { knibbel } & \text { 'the knee' } \\ \boldsymbol{d} \boldsymbol{e} \text { foet } & \text { 'the foot; the leg' }\end{array}$

Schwa-final nouns, also those beginning with a voiceless obstruent, did not undergo this gender change either; see the examples in (13):

(13) The Frisian words for the outer body parts 'side', 'thumb', and 'jaw'

$\begin{array}{ll}\boldsymbol{d} \boldsymbol{e} \text { side } / \mathrm{sid} / \mathrm{H} & \text { 'the side' } \\ \boldsymbol{d} \boldsymbol{e} \text { tomme /tomə/ } & \text { 'the thumb' } \\ \boldsymbol{d} \boldsymbol{e} \text { kake /ka:kə/ } & \text { 'the jaw' }\end{array}$

Nouns ending in schwa are $d e$-words, which appears to be a stronger generalisation over the Frisian lexicon than the one that nouns denoting outer body parts are itwords. Again, the phonological shape of these nouns prevented them from undergoing gender change (see also the previous subsection).

The nouns in (11) —-with the exception of skouder and ankel-are monosyllabic, non-derived words, so that gender change could not be thwarted by the influence of suffixes or word endings on gender assignment. However, words like noas 'nose' and foet 'foot; leg' in (12) above are monosyllabic and underived as well, but they did not acquire a new gender. So, the concept 'outer body part' used here might be in need of further restriction. 
The influence of the gender change of this and the preceding subsection did not affect the overall structure of the Frisian lexicon. In the first place, the number of the nouns involved is relatively small. In the second place, the article $i t$ is not confined to nouns beginning with a voiceless obstruent nor do all de-words begin with a voiced segment (a vowel, a voiced obstruent or a sonorant consonant). The nouns which underwent a change of gender, therefore, could easily fit into the existing Frisian lexicon.

A solid case can be made of a noun-initial voiceless segment as the impetus for the change of gender here. If $i t$-words begin with a voiceless segment, the definite article is either 'original' or it results from gender change. On the other hand, the definite article it is always original for nouns with a voiced initial segment. The latter picture, however, is somewhat blurred by the small number of nouns with a voiced initial segment which became it-words due to analogical extension of the phonologically induced pattern of change.

\subsection{Residual cases}

In (14) below, I list the remaining cases of Frisian it-words with a Dutch $d e$-word as counterpart:

(14) Residual list of nouns

$\begin{array}{lll}\text { Frisian } & \text { Dutch } & \text { gloss } \\ \text { it } \text { aard } & \boldsymbol{d} \text { e } \text { aard } & \text { the nature, the character } \\ \text { it } \text { bit } & \boldsymbol{d} \text { e bijt } & \text { the hole (in the ice) } \\ \text { it } \text { boadskip } & \boldsymbol{d} \boldsymbol{e} \text { boodschap } & \text { the message } \\ \text { it } \text { bûn } & \boldsymbol{d} \boldsymbol{e} \text { bond } & \text { the union, the association, the society } \\ \text { it } \text { grif } & \boldsymbol{d} \boldsymbol{e} \text { griffel } & \text { the slate-pencil } \\ \text { it } \text { helter } & \boldsymbol{d} \boldsymbol{e} \text { halster } & \text { the halter } \\ \text { it } \text { hôf } & \boldsymbol{d} \boldsymbol{e} \text { hof } & \text { the garden } \\ \text { it } \text { laad } & \boldsymbol{d} \boldsymbol{e} \text { la(de) } & \text { the drawer } \\ \text { it } \text { laai } & \boldsymbol{d} \boldsymbol{e} \text { lei } & \text { the slate } \\ \text { it lêst } & \boldsymbol{d} \boldsymbol{e} \text { last } & \text { the burden; the trouble; the cargo } \\ \text { it } \text { rip } & \boldsymbol{d} \boldsymbol{e} \text { ruif } & \text { the rack, the manger } \\ \text { it } \text { rút } & \boldsymbol{d} \boldsymbol{e} \text { ruit } & \text { the (window-)pane }\end{array}$

Unlike the nouns in (11) above, which denote outer body parts, those in (14) do not have a feature in common which could serve as the basis for a (new) semantic gender assignment rule. As to their shape, it is also hard to see what holds them together. Like the nouns in (4) and (11) above, most of them are monosyllabic (to which boadskip ${ }^{21}$ and helter are the exceptions). But in order to explain the change of gender, monosyllabicity in itself is not enough. Though it renders the nouns in (4) and (11) appropriate for hosting a clitic, what is crucial for their change of gender is

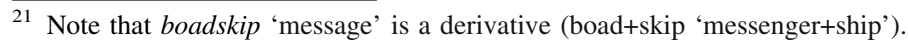


the fact that they begin with a voiceless obstruent. This causes devoicing of the $d$ of the article $d e$, the first step of the reinterpretation of devoiced $d$ as the reduced article $i t$, in the end leading to the replacement of $d e$ by it. None of the nouns in (14), however, begin with a voiceless obstruent. If they do have an initial obstruent at all, it is the voiced plosive /b/ or /g/: bit, bil, boadskip, b ûn, and grif.

This, then, leaves some sort of 'analogy' as the only explanantion for the change of gender here. The change in it aard 'nature, character' may have been induced by the (near)synonym it karakter 'idem'"22. The same may hold for it rút '(window-) pane', next to which there are the semantically related words it raam 'window' and it finster 'idem'. For it laad 'drawer', one might think of the influence of the $i t$-words ending in the same phonological sequence, viz. it haad 'head, chief', it klaad 'robe, garment', it paad 'path(way) ', and also it skaad 'shadow, shade' and it slaad 'lettuce', with gender change induced by their initial $s$ (see (4) above). But the de-words de graad 'degree', de naad 'seam, joint', de saad 'well', and de smaad 'defamation, slander' exist as well, which renders this explanation less convincing. In case of it hôf, the two words hôf, meaning 'court' and 'garden' - originally an $i t$ - and a $d e$-word, respectively-seem to have coalesced, in favour of the it-variant, for which I have no explanation to offer. The latter also holds for the gender change in helter and rip.

All in all, what is at stake here seems to be a random change of gender, for which no semantic or formal explanation is available. This is in marked contrast with the subpatterns of gender change discussed in $\$ \S 5.1$ and 5.2 above, which do lend themselves to a formal and semantic explanation.

\subsection{A comparison of Frisian and Dutch with respect to gender change}

Cliticisation of an unstressed element like the article de onto a following noun, voicing adaptation when the noun in question has an initial voiceless obstruent, and reinterpretation of the adapted article are instances of common linguistic processes. They must have played a role in Dutch as well, which they did. Pauwels (1931) investigated his own dialect, that of Aarschot (Flanders), on the subject of such nouns with a double gender, viz. masculine/feminine (original) and neuter (new). ${ }^{23}$ He found that some nouns with an initial voiceless obstruent behave as neuter when used with the definite article, whereas they are feminine/masculine when the indefinite article is used. Some others have undergone a change of gender, i.e., they have become genuine neuter nouns. But, just as is the case in Frisian, most nouns beginning with a voiceless obstruent have stuck to their original masculine/feminine gender, a fact for which also Pauwels has no explanation to offer.

\footnotetext{
22 karakter is a French loan word. In general, loan words enter Frisian through mediation of Dutch, see Visser (2000). As to nouns, this means that the article is loaned as well. The same goes for neologisms in Frisian, see Sijens (2004). The adaptation and incorporation of loaned nouns provides important clues to how gender assignment 'works' in a given language (Corbett 1991; Thornton 2009). The Frisian-Dutch contact situation, thus, deprives us of these clues.

23 Like most southern varieties of Dutch, the Aarschot dialect still has a three gender system (masculine, feminine, neuter).
} 
In Standard Dutch, however, none of the nouns mentioned by Pauwels-like school 'school', schuur 'shed, barn', sluis 'lock; sluice', straat 'street', and zolder 'attic' - and none of the counterpart words of the Frisian it-words in (4) and (11) (and (14)) have a double gender or have become neuter. This means that Dutch is conservative here and that Frisian is innovative.

In all likelihood, this has to do with differences in the sociological status between the two languages. For centuries, Frisian was a spoken language, which, among other things, was not taught at school. Therefore, it did not develop an explicit standard, be it only for educational purposes. This implies, that the use of it instead of de was not corrected, as it was in Dutch. The Frisian standard language was developed in the nineteenth and twentieth centuries. The substance of Standard Frisian is selected from the Frisian dialects, but in this selection distancing from Dutch plays a major role. That is, those forms are selected which maximally differ from the Dutch forms with which they can be identified (Breuker 1993). So, instead of being rejected as deviant, nouns with a definite article which differs from that of their Dutch counterparts are propagated as pure Frisian, providing all the more evidence that Frisian is a language in its own right and not some Dutch dialect. ${ }^{24}$ So, it kin 'the chin' is pushed forward, to the exclusion of $\boldsymbol{d e}$ kin, which actually is the old form. ${ }^{25}$

\section{From it-word to de-word}

I now turn to the opposite gender change, that is, from it-word to de-word. My claim will be here that the new article, de, is the result of the reanalysis of the old dative form $d e$ of the neuter article.

There are some it-words in Frisian which show up with the article de ('e) in specific environments. The best known example is the word hûs 'house', which has de in some collocational prepositional phrases:

\footnotetext{
24 A rigid way of distancing would be to systematically assign Frisian nouns to the gender (the article) which is the opposite of the Dutch one. In the Frisian-Dutch contact situation, however, distancing is only acceptable if fed by and linking up with real differences in language usage. But Thomason (2006, 348), basing herself on Laycock (1982), mentions an instance of this opposite gender assignment strategy. It concerns dialects of Bougainville Island, Papua New Guinea: "As has been reported from elsewhere in New Guinea, speakers of the Uisai dialect of Buin apparently decided that their speech was too similar to that of their neighbors; without such a decision, followed by deliberate action, it is difficult or impossible to explain the change that distinguishes their dialect: all nouns that are masculine in other dialects of Buin, with all their elaborate gender agreement marking patterns throughout the sentence, are feminine in Uisai, and vice versa. This cannot have been a gradual, incremental change, and it surely was not the result of very young children's innovation."
}

25 See the following quote from early Modern Frisian:

Har onder de kin strijkende

her under the chin stroking

'stroking her chin'

(Feitsma and Bosma (eds) 1961, 171, line 280) 
(15) $d e$-forms of the it-word hûs 'house' in collocational prepositional phrases

it hûs

'the house'

yn 'e hûs ${ }^{26}$

in the house

'inside'

út ' $\boldsymbol{e}$ hûs

out of the house

'having left (of the children) '

(ta) de hûs yn/út

(to) the house in/out

'into/out of the house'

oer $\boldsymbol{d e}$ hûs

over the house

'about the house'

troch $d e$ hûs

through the house

'throughout the house'

These are fixed expressions, in which hîs refers to the familiar house, the house which is assumed to be known to the addressee. Most of the time, this is the house which is the home. If it is about a specific house, the article de is impossible, as the examples in (16) illustrate:

(16) Impossible occurences of de ('e) hûs

Wy wenje yn $\boldsymbol{i t} /{ }^{*} \boldsymbol{e}$ wite hûs dêre

we live in the white house there

'we live in the white house over there'

Hja wenje yn $\boldsymbol{i t} / \boldsymbol{*}^{\prime} \boldsymbol{e}$ hûs op ' $\boldsymbol{e}$ hoeke they live in the house on the corner

'they live in the house on the corner'

The nouns in (17) also show this alternation between it in free use and $d e$ (' $e$ ) in collocational prepositional phrases:

\footnotetext{
$\overline{26}$ ' $e$ is an exclusively enclitic variant of $d e$, mainly occurring after monosyllabic consonant-final prepositions (see also $§ 5.1$ above). 


\begin{tabular}{|c|c|}
\hline $\begin{array}{l}\text { it pleit } \\
\text { 'the plea' }\end{array}$ & $\begin{array}{l}\text { - yn' } \boldsymbol{e} \text { pleit wêze foar } \\
\text { in the plea be for } \\
\text { 'to make a plea for' }\end{array}$ \\
\hline $\begin{array}{l}\text { it praat } \\
\text { 'the talk' }\end{array}$ & $\begin{array}{l}\text { - oan' } \boldsymbol{e} \text { praat hâlde } \\
\text { on the talk hold } \\
\text { 'to keep in play' }\end{array}$ \\
\hline
\end{tabular}

This alternation compares with the one of $d e$-words with de in free use and it ('t) in collocational prepositional phrases, exemplified in (9) above.

The it-words midden 'middle', bosk 'wood', and ein 'end, ending' denote a location. That is the reason why they frequently combine with prepositions designating a relation between an object and a location, in which case they may be accompanied by the article de ('e), as in (18):

$\begin{array}{ll}\text { yn ' } \boldsymbol{e} \text { midden } & \text { 'in the middle' } \\ \text { yn' } \boldsymbol{e} \text { bosk } & \text { 'in the wood' } \\ \text { oan ' } \boldsymbol{e} \text { ein } & \text { 'at the end' }\end{array}$

This could lead to these three nouns becoming de-words. But unlike the change from de to it from the preceding section, the change at hand did not occur anywhere in the Frisian-speaking regions, dependent as it is on extra-linguistic (real-world) factors. Where there are many woods, the word bosk is part of everyday linguistic usage, hence it is more likely to occur in combination with locative prepositions, which in turn renders it more prone to gender change, than in areas without woods. This real-world influence is nicely illustrated by Schiermonnikoogs, the Frisian dialect of the island of Schiermonnikoog. On an island, the beach and the dunes are an important aspect of everyday life. In Schiermonnikoogs, the word straun 'beach' is a neuter word, as is Frisian strân 'idem'. But it often shows up with the article de in collocational prepositional phrases, as (19) illustrates:

(19) de-forms of the it-word straun 'beach' in Schiermonnikoogs ${ }^{27}$

it straun

'the beach'

op 'e straun (also: op straun) ${ }^{28}$

on the beach

'on the beach'

fan 'e straun oof (also: fan straun oof)

from the beach off

'from the beach'

\footnotetext{
27 Also in Frisian this variation is not uncommon. In a text from 1640 the following sentence is found: $E n$ bortet oppe [op 'e = op de] druwge Straan 'and plays on the dry beach' (Feitsma (ed.) 1956b, 47, line 50). And fishermen along the Wadden Sea coast used to haul their fishing vessels op' $\boldsymbol{e}$ strân 'onto the beach' (WFT, Vol. 21, s.v. strân (page 305), citing the Leeuwarder Courant from July 31st 1957).

28 The variation between $d e$ and' $e$ - see $\$ 5.1$ and footnote 26 above-also obtains in Schiermonnikoogs.
} 
by $d e$ straun

by the beach

'near the beach'

by $\boldsymbol{d e}$ straun troch

by the beach through

'along the beach'

ieuwr de straun (also: ieuwr straun)

over the beach

'over the beach'

de faste straun

the steady beach

'the solid sands'

The word dún 'dune', originally a neuter, now belongs to two gender classes, neuter and feminine. In its neuter usage, it has the article de in prepositional phrases.

Gender variation and gender change induced by extra-linguistic (real-world) factors is not likely to be confined to Frisian and its dialects. And indeed it is not. The Standard Dutch words bos 'wood' and strand 'beach' are neuter nouns: het bos and het strand. In the Saxon dialect of the province of Drenthe, bos is also a hetword. But in idiomatic expressions, when following a preposition, bos may have the article de, witness the following two examples, taken from Kocks (1996, 156, s.v. bos):

(20) Examples of de bos from the Saxon dialect of Drenthe

a. Die is ok oet de bos kommen

that one is also out of the wood come

'that one has come from the wood' (meaning: (s)he is uneducated, uncultured, rude)

b. Zien kinder loop nog in de bos

his children walk still in the wood

'his children are still walking in the wood' (meaning: he does not have children of his own)

And in the Dutch dialect of Katwijk aan Zee, an old fishing village by the North Sea coast in the vicinity of the cities of Leiden and The Hague, strand is a de-word (Overdiep 1940, 112). There is a striking parallel with Frisian in this respect. Again, Frisian and Dutch dialects are innovative, whereas Dutch is conservative. As a matter of fact, the latter is what one expects a standard language to be. ${ }^{29}$

\footnotetext{
${ }^{29}$ Because of distancing from Dutch, Standard Frisian is conservative as to the outcome of the historical gender change which is the subject of this article. See also footnote 2 and $\S 5.4$ above. 
Since there does not seem to be a phonological trigger for it, an obvious question is what made gender change possible in this particular case. As is still the case in German, locative prepositions in Old Frisian used to assign dative case to their complement noun. The dative singular form of the neuter definite article/demonstrative pronoun (thet) was tha $(d \bar{a})$ (see Bremmer 2009, 54). From a historical point of view, we may safely assume that the article $d e(' e)$ in some of the above phrases is the continuation of this old dative form. It is, thus, a fossilised or, put differently, a lexicalised form. For $y n^{\prime} \boldsymbol{e}$ hus this must have proceeded as follows: in da huse $\rightarrow$ yn de hûs $\left(\rightarrow y n^{\prime} \boldsymbol{e} h \hat{u} s\right)$.

Nominative case is unmarked in relation to dative case (see Greenberg 1966). Therefore, one may wonder how a dative form can be so persistent here. There are, however, well-defined exceptions to the general markedness conventions, which have consequences for language change. In Tiersma (1982), these are called instances of local markedness, since the general markedness pattern is broken locally. Croft $(2003,165,174)$ prefers the more general term markedness reversal instead, with which I agree. Tiersma (1982, 843) states several principles of markedness reversal, the second one of which, on the face of it, pertains to the case at hand. It reads as follows:

\section{Markedness reversal concerning case assignment}

In languages with case systems, nouns referring to places are locally unmarked in the locative (or another local) case, and nouns referring to tools or instruments are locally unmarked in the instrumental

It is questionable, whether this markedness reversal can be invoked as such for an explanation of gender change in the case at hand. It crucially refers, and pertains, to "languages with case systems". Now, if Frisian does have a case system synchronically, it is one of abstract case only. As with most Germanic languages, it is centuries ago that it lost its system of overt case marking. This means, that case is no longer 'spelled out' on the noun and the article; it only manifests itself indirectly, by means of the thematic role the noun phrase has, as appearing from its place within the syntactic configuration as a whole. This implies that (21) has no direct bearing on the change from $i t$-word to $d e$-word which is the topic of this section.

There may be an indirect bearing though. Nouns denoting a location frequently combine with locative prepositions. ${ }^{30}$ Now, what used to be a prepositional context with overt dative case marking may be said to have developed into a prepositional context with abstract case marking, in line with the general development of case marking in Frisian. The latter context, then, qualifies as the successor of the former.

The above complementary distribution between it and $d e$ and/or the change from $i t$-word to $d e$-word is not a general feature of Frisian it-words which denote a location. Only a handful of these have been affected, whereas most of them-like it doarp 'village', it lân '(piece of) land', and it plein 'square'-do not show a single

\footnotetext{
30 This can be read off from the contexts in which the nouns in questions appear in the Frisian Language Databases (http://www.fryske-akademy.nl/tlb).
} 
trace of it, though they mainly show up in a prepositional context as well. This is a fact for which I have no explanation to offer.

Phonology still has a role to play here. Due to the reduction of its full vowel, the original dative form tha $(d \bar{a})$ of the definite article became homophonic with the generalised (case-neutral) definite article $d e$, which paved the way for their coalescence. Frisian having lost its system of overt case marking, this phonologically induced coalescence was no longer counterbalanced by pressure from the case system.

In early Modern Frisian, the noun in locative prepositional phrases may still have the old dative ending $-e(<-a)$, whereas the article appears in its modern form. See the examples in (22), taken from an early seventeenth century collection of proverbs:

(22) Traces of dative (local) case in early Modern Frisian

Hy tjiennet næt ijne [ijn de] waade/ deert hoiken næt lye mey he ought not in the wood who the squatting down not stand can 'he shouldn't be in the wood who does not like sitting on his heels' (compare Modern Frisian: it wâld 'the wood') (Van der Kuip (2003:368-369, number 466))

Ja frijense oppe [op de] sticke they asked them on the piece 'they asked them (something) in plain terms' (compare Modern Frisian: it stik 'the piece') (Van der Kuip (2003:400, number 535))

T'waer wol verkeere/ de Mountsen binne oppe [op de] fielde the weather will change/ the monks are on the field 'the weather will change (for the better), (because) the wagtails are in the field (after having returned early in the spring)' (compare Modern Frisian: it fjild 'the field') (Van der Kuip (2003:648, number 1067))

In some idiomatic expressions, the noun has retained this original dative ending up till now, witness the examples in $(23):^{31,32}$

\footnotetext{
${ }^{31}$ According to Hoekstra (2006), the final schwa of the noun skerne 'dunghill, dungheap' is the original dative ending of skern 'manure, dung', which has become a fixed part of the lexeme. The same might hold for râne 'edge' and hoeke 'corner'-cf. Dutch rand and hoek; because both denote a location, they mainly occur in a prepositional (dative) context.

32 Dutch has a long and uninterrupted written tradition, whereas Frisian mainly functions as a spoken language. That is why many more of such expressions have been retained in Dutch than in Frisian. Some Dutch examples are: in den beginne 'in the beginning' (next to het begin 'the beginning'), om den brode 'for a living, for the money' (next to het brood 'the bread; the loaf'), iets aan den lijve ondervinden 'experience something personally' (next to het lijf 'the body'), het gaat hem naar den vleze 'he does good business, trade' (next to het vlees 'the flesh; the meat'), and met dien verstande 'on the understanding that, provided (that) ' (next to het verstand 'the intellect, mind, reason'). Such phrases give one's linguistic usage a distinguished flavour.
} 
(23) Traces of dative (local) case in Modern Frisian

yn'e lytse loege sitte/wêze

in the small spot sit/be

'to be in a tight spot/corner'

(compare the Old Frisian neuter noun: thet loch 'the spot')

immen $u$ t' $\boldsymbol{e}$ leage waskje

someone out of the caustic solution wash

'to haul someone over the coals'

(compare the Modern Frisian neuter noun: it leach 'the caustic solution')

The existence of the expression immen út'e leage waskje in (23) and the ones with hûs in (15) above-like yn'e hûs, út'e hûs, and oer de hûs-does not imply that leach and hîs have a double gender, i.e., that they are both it- and de-words. These nouns are associated with the article it, of which $d e$ is a lexicalised combinatorial variant. This also holds for pleit 'plea' and praat 'talk' in (17) above. ${ }^{33}$

As noted before, nouns denoting a location frequently occur with locative prepositions, providing a context in which typically the variant $d e(' e)$ may show up. This, in turn, may lead to the generalisation of the latter, implying a change of gender. The nouns in (24) are instances of this:

(24) Nouns which underwent a change of gender $(i t \rightarrow$ de)

de mar 'the lake'

(compare older Frisian: it mar 'idem'; compare Dutch: het meer 'idem')

de $\mathrm{middel} / \mathrm{mil} / \mathrm{mul}$ 'the waist, the middle'

(compare Dutch: het middel 'idem')

Some nouns denoting a location, which originally are neuter, show dialectal and idiolectal variation between it and $d e$. This is the case with midden 'middle', bosk 'wood', and ein 'end, ending' in (18) above. Standard Frisian chooses the article de here, since it provides a maximal contrast, genderwise, with the neuter Dutch counterparts het midden 'middle', het bos 'wood', and het eind(e) 'end, ending'.

\section{Conclusion}

In Frisian, grammatical gender is not spelled out on the noun directly. It manifests itself in an indirect way, through the agreement relations the noun enters into. This means that the language user has no formal clues as to the gender which a bare noun is allotted to.

Since the gender of a noun is only detectable from the context in which the noun occurs, an obvious source of gender change is the reinterpretation of surface forms. It is, thus, understandable that phonological regularities and residual (abstract) case

\footnotetext{
33 These nouns do not denote a location, so some sort of analogical pattern extension must be at stake, which I will not go into here.
} 
marking in a prepositional context can be crucial for two instances of historical gender change in Frisian. But factors which, strictly speaking, are non-linguistic in nature can play a role as well, especially in the Dutch-Frisian language contact situation. These factors are, first, the low degree of standardisation of Frisian at the time the gender change set in and, secondly, distancing from Dutch at the time when Frisian developed its own standard vis-à-vis Dutch, which implies the propagation of the gender which diverges from the Dutch one.

It would be wrong, however, to conclude that as far as gender change is concerned 'anything goes'. Not every Frisian $d e$-word could become an it-word and vice versa, since the language system puts its limits here. For instance, all nouns ending in schwa are $d e$-words, a formal regularity which prevented them from switching to it-words.

It would also be wrong to conclude that there are only regular patterns of gender change. In Frisian, one has subpatterns at best. There are a few general tendencies, but as far as individual words are concerned, there is much that must be left unexplained.

Acknowledgements I am deeply indebted to Geert Booij, without whose help and encouragement this article would not have existed. Thanks are due to my colleagues Siebren Dyk, for his comments on a preliminary version, and Jarich Hoekstra, with whom I once wrote an article, in Frisian, on the same subject (Hoekstra and Visser 1996). I would also like to thank the editors of Morphology and three anonymous reviewers for their generous and valuable comments. All disclaimers apply.

Open Access This article is distributed under the terms of the Creative Commons Attribution Noncommercial License which permits any noncommercial use, distribution, and reproduction in any medium, provided the original author(s) and source are credited.

\section{References}

Booij, G. E. (1995). The Phonology of Dutch (=The phonology of the world's languages; 2). Oxford: Clarendon Press.

Booij, G. E. (1996). Cliticization as prosodic integration: The case of Dutch. The Linguistic Review, 13, 219-242.

Booij, G. E. (2002). The morphology of Dutch. Oxford: Oxford University Press.

Bremmer, R. H. Jr. (2009). An introduction to Old Frisian: History, grammar, reader, glossary. Amsterdam/Philadelphia: John Benjamins publishing Company.

Breuker, P. (1993). Noarmaspekten fan it hjoeddeiske Frysk [Aspects of the standard of present-day Frisian] (Doctoral dissertation, Rijksuniversiteit, Groningen).

Brouwer, J. H. (Ed.). (1959). De Fryske fersen fan Durk Lenige en oare Makkumers [The Frisian poems of Durk Lenige and other people from Makkum] (=Magnus-rige; 8). Boalsert: A.J. Osinga.

Corbett, G. G. (1991). Gender (Cambridge textbooks in linguistics). Cambridge: Cambridge University Press.

Croft, W. (2003). Typology and universals (Cambridge textbooks in linguistics) (2nd ed.). Cambridge: Cambridge University Press.

de Haan, G. J. (1997). Contact-induced changes in modern West Frisian. Us Wurk, 46, 61-89.

Dresher, B. E., \& van der Hulst, H. (1998). Head-dependent asymmetries in phonology: Complexity and visibility. Phonology, 15, 317-352.

Enger, H.-O. (2009). The role of core and non-core semantic rules in gender assignment. Lingua, 119, $1281-1299$.

Feitsma, A. (Ed.). (1956a). Oude Friesche spreeck-woorden, Franeker 1641, synoptysk mei Friesche bywirden, Hs. Gabbema, mei dêroan taheakke oantekeningen fan Franciscus Junius F.F. en Janus 
Vlitius [text edition of collections of early Modern Frisian proverbs, with scholarly notes] (= Estrikken; XI). Grins: Frysk Ynstitút oan de Rijksuniversiteit Groningen.

Feitsma, A. (Ed.). (1956b). Frysk út de 17de ieu, teksten en fragminten, mei chronologysk en alfabetysk register [Frisian from the 17 th century, texts and fragments, with a chronological and alphabetical index] (= Estrikken; XV). Grins: Frysk Ynstitút oan de Rijksuniversiteit Groningen.

Feitsma, A., \& Bosma, R. (Eds.). (1961). Frysk út de 18de ieu, teksten en fragminten, diel III: 1763-1779 [Frisian from the 18th century, texts and fragments, part III: 1763-1779] (= Estrikken; XXII). Grins: Frysk Ynstitút oan de Rijksuniversiteit Groningen.

Frysk Wurdboek. (1984). (Frisian-Dutch desk dictionary, edited by J.W. Zantema).

Greenberg, J. H. (1966). Language universals, with special reference to feature hierarchies (Janua Linguarum, Series Minor, 59). The Hague: Mouton.

Hayes, B. (1989). Compensatory lengtening in moraic phonology. Linguistic Inquiry, 20, 253-306.

Hilarides, J. (1705). Niewe Taalgronden/ Der Neederdujtsche Taal;/ Weegens/ Het Gebrujk der Voorleedekens/,/ de/, den: die; deezel, dit/, dat/, het;/ en de/ Neederlantsche Woordrekkinge;/ voor/ Daavid van Hoochstraaten Med. Doct./ en conrector t' Amsterdam./ Opgesteld door/ Johannes Hilarides. Fraaneker: Jacobus Horreus.

Hoekstra, J. (2001). Standard West Frisian. In: H. H. Munske (Ed.; in collaboration with Århammar, N., Faltings, V. F., Hoekstra, J. F., Vries, O., Walker, A. G. H., \& Wilts, O.), Handbuch des Friesischen/ Handbook of Frisian Studies (pp. 83-98). Tübingen: Max Niemeyer Verlag.

Hoekstra, J. (2006). Westerlauwerskfrysk etymologysk griemmank (III) [Westerlauwers Frisian etymological miscellany]. Us Wurk, 55, 140-154.

Hoekstra, J., \& Visser, W. (1996). De- en it-wurden yn it Frysk [de- and it-words in Frisian]. Us Wurk, 45, 55-78.

Kocks, H. G. (1996). Woordenboek van de Drentse dialecten, A-L [Dictionary of the dialects of Drente, A-L]. Assen: Van Gorcum.

Laycock, D. C. (1982). Melanesian linguistic diversity: A Melanesian choice? In: R. May \& H. Nelson (Eds.), Melanesia: beyond diversity (pp. 33-38). Canberra: Australian National University Press.

Lombardi, L. (1999). Positional faithfulness and voicing assimilation in optimality theory. Natural Language and Linguistic Theory, 17, 267-302.

Nielsen, H. F. (1981). Old English and the continental Germanic languages: a survey of morphological and phonological interrelations (= Innsbrucker Beiträge zur Sprachwissenschaft; Band 33). Innsbruck: Institut für Sprachwissenschaft der Universität.

Overdiep, G. S. (1940). De volkstaal van Katwijk aan Zee [The vernacular of Katwijk aan Zee]. Antwerpen: N.V. Standaard-Boekhandel.

Pauwels, J. L. (1931). Substantieven met een dubbel Grammatisch Geslacht [nouns with a double grammatical gender]. Leuvensche bijdragen op het gebied van de Germaanse philologie, 23, 84-104.

Shields, K. (1979). A theory of gender change. Glossa, 13, 27-38.

Sijens, H. (2004). Neologismen yn it Frysk. 'Wat wy net hawwe, dat liene wy' [Neologisms in Frisian. 'What we do not have, that we loan']. It Beaken, 66, 256-298.

Spenter, A. (1971). Die Genuskategorie in der Schiermonnikooger Mundart. Us Wurk, 20, 27-36.

Thomason, S. G. (2006). Language change, intentional. In: K. Brown (Ed.), Encyclopedia of language and linguistics (2nd ed., pp. 346-349). Oxford: Elsevier.

Thornton, A. M. (2009). Constraining gender assignment rules. Language Sciences, 31, 14-32.

Tiersma, P. M. (1982). Local and general markedness. Language, 58, 832-849.

Tiersma, P. M. (1985). Frisian reference grammar. Dordrecht: Foris Publications.

van der Kuip, F. J. (2003). De Burmania-sprekwurden. Santjinde-ieuske Fryske sprekwurden ferklearre en yn har tiid besjoen [The (so-called) Burmania-proverbs. Seventeenth century Frisian proverbs explained and viewed in the context of their time]. Ljouwert/Leeuwarden: Fryske Akademy.

Visser, W. (1988a). In pear klitisearringsferskynsels yn it Frysk [Some cliticisation phenomena in Frisian]. In: S. Dyk \& G. de Haan (Eds.), Wurdfoarried en Wurdgrammatika. In bondel leksikale stúdzjes [Lexis and word grammar. A collection of lexical studies] (pp. 175-222). Ljouwert: Fryske Akademy.

Visser, W. (1988b). Wêrom't progressive assimilaasje yn it Frysk net bestiet [Why progressive assimilation does not exist in Frisian]. Tydskrift foar Fryske Taalkunde, 4, 1-20.

Visser, W. (1990). From modern Frisian to old Frisian: On cliticisation of the definite article. In: R. H. Bremmer Jr., G. v.d. Meer, \& O. Vries (Eds.), Aspects of old Frisian philology (pp. 466-482). (= Amsterdamer Beiträge zur älteren Germanistik, Band 31/32 / Estrikken; 69). Amsterdam: Rodopi and Groningen/Grins: SSFYRUG.

Visser, W. (1997). The syllable in Frisian (Doctoral dissertation, Vrije Universiteit, Amsterdam). 
Visser, W. (2000). Frjemd wurdt eigener. Oer de âlde Frânske lienwurden yn it Frysk [Foreign becomes more familiar. On the old French loan words in Frisian]. It Beaken, 62, 141-218.

WFT. (1989-2010). Wurdboek fan de Fryske taal/Woordenboek der Friese taal [Dictionary of the Frisian language]. Ljouwert: Fryske Akademy. 